\title{
Non-residential Fatherhood and Child Involvement: Evidence from the Millennium Cohort Study
}

\author{
Kathleen Kiernan
}

\section{Contents}

Introduction

A profile of non-partnered parents and their children

Involvement of the father at the time of the birth

Characteristics of non-resident and resident fathers

Resident fathers engagement with their baby

Non-resident fathers contact and involvement at 9 months

Contact and payment of maintenance

Frequency of involvement

Interest in the child and parental relations

Overview and conclusions

References

CASEpaper 100

May 2005
Centre for Analysis of Social Exclusion

London School of Economics

Houghton Street

London WC2A 2AE

CASE enquiries - tel: 02079556679 


\section{Centre for Analysis of Social Exclusion}

The ESRC Research Centre for Analysis of Social Exclusion (CASE) was established in October 1997 with funding from the Economic and Social Research Council. It is located within the Suntory and Toyota International Centres for Economics and Related Disciplines (STICERD) at the London School of Economics and Political Science, and benefits from support from STICERD. It is directed by Howard Glennerster, John Hills, Kathleen Kiernan, Julian Le Grand, Anne Power and Carol Propper.

Our Discussion Paper series is available free of charge. We also produce summaries of our research in CASEbriefs, and reports from various conferences and activities in CASEreports. To subscribe to the CASEpaper series, or for further information on the work of the Centre and our seminar series, please contact the Centre Administrator, Jane Dickson, on:

$\begin{array}{ll}\text { Telephone: } & \text { UK+207955 6679 } \\ \text { Fax: } & \text { UK+2079556951 } \\ \text { Email: } & \text { j.dickson@lse.ac.uk } \\ \text { Web site: } & \text { http://sticerd.lse.ac.uk/case }\end{array}$

(C) Kathleen Kiernan

All rights reserved. Short sections of text, not to exceed two paragraphs, may be quoted without explicit permission provided that full credit, including (C) notice, is given to the source. 


\title{
Editorial Notes and Acknowledgments
}

Kathleen Kiernan is Professor of Social Policy and Demography at the University of York and Co-Director of CASE. The ESRC provided support for this project and the Millennium Cohort data were provided by the ESRC Data Archive at Essex University. I would like to thank Jonathan Bradshaw, John Hobcraft and Penny Mansfield for their very helpful comments.

\begin{abstract}
Fifteen per cent of British babies are now born to parents who are neither cohabiting nor married. Little is known about non-residential fatherhood that commences with the birth of a child. Here, we use the Millennium Cohort Study to examine a number of aspects of this form of fatherhood. Firstly, we consider the extent to which these fathers were involved with or acknowledged their child at the time of the birth. Secondly, we identify the characteristics that differentiate parents who continue to live apart from those who move in together. Thirdly, for the fathers who moved in with the mother and their child we enquire whether they differ in the extent of their engagement in family life compared with fathers who have been living with the mother since birth. Finally, for fathers who were living apart from their child when the child was 9 months old we assess the extent to which they were in contact, contributed to their maintenance and were involved in their child's life at this time.
\end{abstract}

JEL classification: I30, I39, J12, J13, J18, K19

Key words: non-resident fathers, ethnic families, fatherhood, father involvement, unmarried mothers, non-marital births, cohabiting parents 


\section{Introduction}

Amongst policy makers, families and scholars over recent decades there has been growing concern and interest in the role that non-resident fathers play in the lives of their children, and more recently in the phenomenon of unmarried parenthood and the appropriate rights and responsibilities of such fathers (Home Office, 1998; Lewis, 2001; Barlow, 2004). Across most developed societies there have been noticeable increases in the number of children born to unmarried parents, with most of this increase being due to the rise in births to cohabiting couples. However, in Britain there has also been an increase in the proportions of all babies born to parents who are not living together at the time of the birth (Kiernan, 2004) and the proportions of children who commence their lives without a father present is higher in Britain than in most other European countries (Andersson, 2002 ). It is this new phenomenon of nonresidential fatherhood that is the focus of this paper.

With the rise in divorce and non-marital childbearing, nowadays men spend less time in marriage and with their children than was the case in the recent past (Bianchi, 1998). Fatherhood has seemingly become a more voluntary role. Although some men may not even be aware that they have fathered a child, those who are aware have varied responses to paternity, with some men choosing not to be involved in their children's lives, whilst others embrace the role with enthusiasm (Lewis, 2000). The degree of attachment to the mother also varies; some fathers are formally attached through the bonds of marriage whilst others form more informal relationships both within and across households. In such relationships, the social norms that define roles and responsibilities may be less clear cut than those in formal marriages (Furstenberg, 1988; Maclean and Eekelaar, 1997; Lewis, 2001).

Very little is known about non-residential fatherhood that begins at the transition to parenthood rather than after the breakdown of a marriage or cohabiting union. Such fathers are largely statistically invisible and little is known about the extent to which these fathers maintain a relationship with their children or what form this takes. The advent of the UK Millennium Cohort Study (MCS) allows us to examine some of these issues for a large, nationwide sample of new parents and their children. The MCS baseline study took place in 2001-2 and collected information from over 18000 families at the time their child was around 9 months old. ${ }^{1}$ The study over sampled for ethnic minority

1 All the interviews took place over a period when the baby was 9-11 months old but the great majority of the babies were 9 months old at the time of the interview. 
families and children living in areas with high rates of child poverty as well as the smaller countries of the UK, Scotland, Wales and Northern Ireland (see Shepherd et al, 2004 and Smith and Joshi, 2002 for more details).

For the MCS sample we estimate that 60 per cent of babies were born to married couples, which is identical to the proportion found from Birth Registration data (ONS, 2004), 25 per cent were born to cohabiting couples and 15 per cent were born to parents who were not in a co-residential partnership at the time of the birth (Kiernan and Smith, 2003). As yet we do not have established terms for this latter group but for ease of description here I will refer to these parents as 'solo' mothers and non-resident fathers.

Given the novel nature of the data we will examine a number of aspects of fatherhood for the subset of fathers who were not living with mother at the time of the birth. Firstly, we consider the extent to which fathers were involved with or acknowledged their child at the time of the birth, as judged by whether they were present at the birth of their child, and whether they were included on the child's birth certificate. Secondly, given that some fathers who were not resident at the time of the birth subsequently moved in with the mother and their child, whilst others continue to live apart we examine the characteristics that differentiate parents who continue to live apart from those who move in together. Thirdly, for the fathers who 'moved in' with the mother and their child we enquire whether they differ in the extent of their engagement in family life compared with fathers who have been living with the mother since birth. ${ }^{2}$ Finally, for fathers who were living apart from their child when the child was 9 months old we assess the extent to which they were in contact, contributed to their maintenance and were involved in their child's life at this time. ${ }^{3}$

\section{A profile of non-partnered parents and their children}

To set the scene we start with a brief description of the characteristics of the parents who were not in a partnership at the time of the birth and how they compare with married and cohabiting parents. ${ }^{4}$ Table 1 provides background

'Moved in' is an imprecise concept as no information was collected on whether the father moved in with the mother or vice versa.

3 All of the information on non-resident fathers including that on whether the father was present at the birth and whether they were included on the child's birth certificate was provided by the mothers reports, as unfortunately non-resident fathers were excluded from the study due to lack of financial resources.

For more details on comparisons between these type of families see Kiernan and Smith (2003). 
information on the age of the parents, educational attainment and ethnicity of the mother and Table 2 gives information provided by the mother on the pregnancy and birth: including the baby's parity, whether the baby was planned, whether the father was at the birth and was on the child's birth certificate.

From Table 1 we see that the parents not in a union at the time of the birth, numerically speaking, were not predominantly young parents; 44 per cent of the solo mothers and 63 per cent of the non-resident fathers were over age 25 . But on average they were substantially younger than their married and cohabiting counterparts. Solo mothers and cohabiting mothers were more likely than married mothers to be having their first child, but even amongst these groups one in two of the mothers were having a second or later child. The human capital of these families as assessed by the mother's educational attainment was also much lower than that seen amongst the married and cohabiting groups. The great majority of the solo mothers, 86 per cent, were white mothers; the next two biggest groups were the Black Caribbean and Black African groups (4 per cent each); and the smallest groups were those from the Indian sub continent. We also note that giving birth within a cohabiting union is relatively rare amongst all the ethnic minority groups, and marriage is a relatively more common setting amongst the Asian families. There was also a marked spatial variation by type of parental union at birth. Over half of the out of union births occurred to parents who lived in disadvantaged wards compared with one in four of the marital births.

Mothers were asked whether the baby had been planned or whether the pregnancy had been a surprise. From Table 2 we see that only 16 per cent of the babies born to non-resident parents were planned compared with 74 per cent of those born to married couples and 47 per cent of those born to cohabiting couples. Despite the lack of planning amongst the parents not in a union, these fathers identified sufficiently with their paternity for 45 per cent to be present at the birth, and 63 per cent were included on the birth certificate. Unsurprisingly, these were substantially lower proportions than those observed amongst married and cohabiting fathers, amongst whom more than 90 per cent were present at the birth, and virtually all the cohabiting fathers were included on the child's birth certificate. 
Table 1 Characteristics of families according to the partnership context of the parents at the time of the birth*

\begin{tabular}{|c|c|c|c|}
\hline Characteristic & $\begin{array}{c}\text { Solo } \\
\%\end{array}$ & $\begin{array}{c}\text { Cohabiting } \\
\% \\
\end{array}$ & $\begin{array}{c}\text { Married } \\
\% \\
\end{array}$ \\
\hline \multicolumn{4}{|l|}{ Mother's age at birth } \\
\hline Under 20 & 26 & 11 & 1 \\
\hline 20-24 years & 30 & 26 & 9 \\
\hline $25-29$ years & 20 & 29 & 29 \\
\hline 30 and older & 24 & 34 & 61 \\
\hline \multicolumn{4}{|l|}{ Father's age at birth } \\
\hline Under age 24 & 37 & 22 & 4 \\
\hline 25-34 years & 42 & 54 & 58 \\
\hline 35 and older & 21 & 24 & 38 \\
\hline \multicolumn{4}{|l|}{ Parity of child } \\
\hline$\%$ first born & 52 & 51 & 37 \\
\hline \multicolumn{4}{|c|}{ Educational qualifications } \\
\hline None & 28 & 13 & 8 \\
\hline NVQ level 1/3 & 62 & 63 & 49 \\
\hline NVQ level 4/5 & 10 & 24 & 43 \\
\hline \multicolumn{4}{|l|}{ Mother's ethnic origin } \\
\hline White & 85.9 & 96.9 & 86.7 \\
\hline Mixed & 2.3 & 0.7 & 0.7 \\
\hline Indian & 0.9 & 0.1 & 2.8 \\
\hline Pakistani & 1.4 & 0.1 & 4.5 \\
\hline Bangladeshi & 0.3 & 0.0 & 1.5 \\
\hline Black Caribbean & 3.7 & 0.7 & 0.6 \\
\hline Black African & 3.8 & 0.8 & 1.1 \\
\hline Other & 1.8 & 0.6 & 2.1 \\
\hline \multicolumn{4}{|l|}{ Type of ward } \\
\hline Advantaged & 35 & 56 & 68 \\
\hline Disadvantaged & 55 & 43 & 26 \\
\hline Ethnic & 8 & 2 & 5 \\
\hline Number in the sample & 3491 & 4369 & 10615 \\
\hline
\end{tabular}

* The statistics in this and subsequent tables are based on weighted data and were derived from the survey commands in STATA designed for weighted data (STATA, 2003). The differences across the groups on these characteristics were all significant at the level of 1 in 10000. 
Table 2: Pregnancy and birth characteristics according to the partnership context of the parents at the time of the birth*

\begin{tabular}{lccc}
\hline \hline Characteristic & $\begin{array}{c}\text { Solo } \\
\mathbf{\%}\end{array}$ & $\begin{array}{c}\text { Cohabiting } \\
\mathbf{\%}\end{array}$ & $\begin{array}{c}\text { Married } \\
\mathbf{\%}\end{array}$ \\
\hline Baby planned & 16 & 47 & 79 \\
Baby surprise & 84 & 53 & 26 \\
Father present at birth & & & \\
Yes & 45 & 92 & 93 \\
No & 55 & 8 & 7 \\
Father on the birth certificate & & & \\
Yes & 63 & 97 & Not \\
No & 37 & 3 & applicable \\
Number in the sample & 3491 & 4369 & 10615 \\
\hline \hline
\end{tabular}

* The differences across the groups on these characteristics were significant at the level of 1 in 10000 .

\section{Involvement of the father at the time of the birth}

Being present at the birth or inclusion on the child's birth certificate suggests some degree of closeness and involvement around the time of the birth.

Moreover, the policy implications of these indicators are of some importance. Since July 2001 in Northern Ireland and from December 2003 in England and Wales fathers who jointly registered the birth of their baby have had equal parental responsibility akin to married parents. Parental responsibility provides important legal rights such as the ability to be involved in decisions pertaining to the child's residence, education, religion and medical treatment. Unmarried fathers in Scotland (at the time of writing) do not have this right. The great majority of the unmarried fathers in the MCS study do not have this automatic right as only 3 per cent of the babies were born in Northern Ireland. Thus the majority of unmarried fathers of the MCS children can only acquire parental responsibility by either marrying the child's mother, or by obtaining a Parental Responsibility Agreement (PRA) signed by the mother; if the mother does not agree to a PRA the father can apply to the courts for a Parental Responsibility Order. Facts such as being on the birth certificate or being present at the birth of the child tend to count favourably in such submissions (Families Need Fathers website www.fnf.org.uk).

As we saw in Table 2, amongst the set of non-resident fathers 63 per cent were included on the birth certificate, which was a higher proportion than the 45 per 
cent reported as having been present at the birth. ${ }^{5}$ As might be expected there was a degree of overlap between the groups of fathers present at the birth and included on the birth certificate but they were not co-terminous behaviours. Forty per cent of the non-resident fathers were present at the birth and on the birth certificate, 32 per cent were on neither, 23 per cent were registered on the birth certificate as the father but were not present at the birth, and a tiny minority of the fathers, 5 per cent, were present at the birth but not included on the birth certificate. Information on whether the father was present at the birth of the child provides an indication of the degree of closeness of the father to the mother and child at birth, and may well be an important determinant of future contact and involvement; which we investigate below.

\section{Characteristics of non-resident and resident fathers}

At the time of the interview, when the cohort baby was around 9 months old, 84 per cent of all the fathers of the Millennium Cohort children were living with their child, 2 per cent were living part-time in the home, and 14 per cent of the fathers were non-resident at this time. The great majority, 84 per cent, of the fathers who were non-resident at this time were also non-partnered at the time of the birth; the remainder were cohabiting (12 per cent) and married fathers ( 4 per cent) who had separated from the mother since the birth of their child.

Our focus remains on the fathers of the 15 per cent of children who were born outside of a union. At the time of the 9 month-old-interview, 24 per cent of these fathers were living with the mother and their child, made up of 14 per cent who were living there full-time and 10 per cent part time. Thus, part-time residence is an important component of the family structure of these families. For these three sub-sets of fathers we investigated to what extent they differed with respect to the degree of involvement at birth and how they compared on a range of characteristics: including age at parenthood, educational level of the mother, gender and parity of the baby, type of area and ethnicity. However, with the exception of father involvement at birth and ethnicity we found no

The question put in the MCS study was whether the father's name was on the birth certificate. However, this does not imply that the birth was jointly registered. Mothers can give the child the same surname as the father without his presence or permission. A project by One plus One who have been working with Registrars on this topic has found that some mothers regard this as acknowledging the father or identifying that the father is not unknown. Registrar's also report that the families of new parents often put pressure on the father to attend so that the child's certificate has information in the section about the father and thus the child is not regarded as being fatherless.(Personal Communication Penny Mansfield, One plus One). 
statistically significant difference across and between the sets of fathers on these characteristics and only report on these two aspects in Tables 3 and $4 .^{6}$

Table 3: Father involvement at birth and whether resident or not at 9 months

\begin{tabular}{lcccc}
\hline \hline Father involvement at birth & $\begin{array}{c}\text { Resident, } \\
\text { full-time }\end{array}$ & $\begin{array}{c}\text { Resident } \\
\text { part-time }\end{array}$ & $\begin{array}{c}\text { Non- } \\
\text { resident }\end{array}$ & Total \\
\hline Present at birth \% & 69 & 72 & 37 & 45 \\
On the birth certificate \% & 81 & 90 & 56 & 63 \\
& 6 & 2 & 92 & 100 \\
$\begin{array}{l}\text { Father neither at the birth nor on the } \\
\text { birth certificate }\end{array}$ & 11 & 9 & 80 & 100 \\
On birth certificate only & 14 & 8 & 78 & 100 \\
At the birth only & 23 & 16 & 61 & 100 \\
At the birth and on the birth certificate & & & & \\
& 521 & 331 & 2663 & 3515 \\
Numbers in sample & 14 & 10 & 76 & 100 \\
Percentage & & & & \\
\hline \hline
\end{tabular}

From the upper part of Table 3 we see that the two sets of resident fathers compared with those who were non-resident were much more likely to have been present at the birth and to have been named on the child's birth certificate. In the lower part of the table we take a different perspective and ask what proportions of fathers who were present at the birth or on the birth certificate were resident or not by the time the child was 9 months old. Additionally, we have combined the two behaviours present at birth and on the birth certificate to assess the relative importance of these two elements. We see that where the father was present at the birth and on the birth certificate, 4 out of 10 of these fathers were living with the mother at least part of the time whereas where they were neither at the birth nor on the certificate only 8 per cent were doing so. Where the fathers were only on one or other there was little difference between being present at the birth or being on the birth certificate in the propensity to be

6 Information on the father's ethnicity was collected from the mothers where the father was non-resident and co-resident partners of the mother supplied information on their ethnic group. However, there was a high non-response rate on the partner's questionnaire with information missing for 13 per cent of this group. Given this problem for the comparison of non-resident father's and resident fathers we use mother's ethnic group but for our specific analysis of non-resident fathers, which follows we use the information collected on their own ethnic group. 
living with the mother, and these fathers were intermediate between the two end groups in the extent to which they were non-resident.

Table 4: Residential situation according to the ethnic group of mother

\begin{tabular}{lcccc}
\hline \hline Ethnic group & $\begin{array}{c}\text { Resident, } \\
\text { full-time }\end{array}$ & $\begin{array}{c}\text { Resident, } \\
\text { part-time }\end{array}$ & $\begin{array}{c}\text { Non- } \\
\text { resident }\end{array}$ & $\begin{array}{c}\text { Total } \\
\text { number } \\
\mathbf{N = 1 0 0 \%}\end{array}$ \\
\hline White & 14 & 10 & 76 & 2875 \\
Mixed & 11 & 16 & 72 & 90 \\
Indian & 61 & 0 & 39 & 56 \\
Pakistani & 26 & 5 & 69 & 75 \\
Bangladeshi & 35 & 0 & 65 & 21 \\
Black Caribbean & 3 & 12 & 85 & 145 \\
Black African & 5 & 6 & 89 & 171 \\
Other & 36 & 7 & 56 & 80 \\
& & & & \\
Numbers in sample & 522 & 308 & 2683 & 3513 \\
Percentage & 14 & 10 & 76 & 100 \\
\hline \hline
\end{tabular}

There were also some differences according to the mother's ethnicity and the father's living arrangements. From Table 4 we see that relatively speaking, black mothers were less likely to be living with the father of their child, whereas those of Asian origins were more likely to be living with the child's father. These findings are in accord with other British studies of ethnicity and family structure, particularly studies of lone-mother families, (ONS, 1996; Scott et al, 2001). We also see amongst Black mothers, particularly those of Caribbean origin, that the father of their child is substantially more likely to be living there on part-time rather than a full-time basis whereas amongst the Asian mothers it is very rare for the father to be living there on a part-time basis. ${ }^{7}$

\section{Resident fathers engagement with their baby}

For the group of fathers who had 'moved in' with the mother we went on to enquire whether these resident fathers who had been more loosely connected to the mother at the time the baby was born, are less engaged with their child than resident fathers who were married or cohabiting with the mother at the birth. In other words, amongst fathers living with their child, does the level of

7 All the highlighted differences were statistically significant at 0.05 or better. 
engagement with the child differ according to the partnership context in which the child was born? We explored this issue using responses made by the father to a set of questions on their involvement with the baby, namely: how often they looked after the baby on their own; changed the baby's nappy; and how often they feed the baby, each of which we divided into two categories, at least once a day versus less frequently. ${ }^{8}$

Table 5 shows the proportions of fathers who carried out these activities at least once a day according to whether the parents were married, cohabiting or not in a partnership at the time of the birth. The latter group was sub-divided into whether they were living with the mother full-time or part time. Not surprisingly fathers who were only living there part-time were less likely than the other fathers to be involved with their child on a daily basis. However, fathers who were not in partnership with mother at the time of the birth but were now living with the mother on a full-time basis were not significantly different from the other two groups of parents in the extent to which they were involved with their baby. This suggests that amongst fathers who live with their child, at least for baby-father involvement, there is little negative legacy of the partnership status at birth.

Table 5: Resident father involvement with their child according to partnership context at birth

\begin{tabular}{|c|c|c|c|c|}
\hline \multirow[t]{2}{*}{ Characteristic } & $\begin{array}{l}\text { Resident } \\
\text { father }\end{array}$ & $\begin{array}{l}\text { Resident } \\
\text { father }\end{array}$ & $\begin{array}{l}\text { Resident } \\
\text { father - } \\
\text { full-time }\end{array}$ & $\begin{array}{c}\text { Resident } \\
\text { father - } \\
\text { part-time }\end{array}$ \\
\hline & $\begin{array}{l}\text { Married at } \\
\text { birth }\end{array}$ & $\begin{array}{l}\text { Cohabiting } \\
\text { at birth }\end{array}$ & $\begin{array}{c}\text { Not in a } \\
\text { union at } \\
\text { birth }\end{array}$ & $\begin{array}{c}\text { Not in a } \\
\text { union at } \\
\text { birth }\end{array}$ \\
\hline \multicolumn{5}{|l|}{ At least once a day } \\
\hline $\begin{array}{l}\% \text { who look after the baby } \\
\text { on their own }\end{array}$ & 31.4 & 31.9 & 35.6 & 23.1 \\
\hline $\begin{array}{l}\% \text { who change the baby's } \\
\text { nappy }\end{array}$ & 56.9 & 59.4 & 56.2 & 41.1 \\
\hline$\%$ who feed the baby & 52.3 & 56.1 & 58.7 & 45.0 \\
\hline Number in sample & 10446 & 3992 & 521 & 373 \\
\hline
\end{tabular}

8 Unlike most of the information we have been using this information was collected directly from the fathers living with mother on either a full or part time basis. 


\section{Non-resident fathers contact and involvement at 9 months}

The majority of fathers who were not in a union at the time of the birth (76 per cent) had not moved in with the mother and their child, but many were still in involved in their children's lives. Again we have to rely on information collected from the mothers on the extent to which non-resident fathers were in contact with her and their child, and amongst the fathers who were in contact the extent of their involvement in their child's lives. Amongst the fathers who were non-partnered at birth and were residentially separated from their 9 monthold-child, 59 per cent were still in contact with the mother and baby. For the fathers who were in contact, the mothers were asked a few questions which provided information on: the level of interest the father showed in the child; the frequency with which he saw his child; and the degree of friendliness between herself and the father. Amongst our set of non-resident fathers who were in contact with the mother 65 per cent were described as being very interested in their child, 77 per cent saw their child at least once a week, and in 76 per cent of the cases mothers reported that they were on friendly or very friendly terms with the father. All the mothers whether they were in contact or not, were asked whether the father contributed any money to the child's maintenance: 29 per cent of this set of non-resident fathers made some contribution to the child's maintenance either on a regular or irregular basis.

We have shown that the extent of involvement at birth amongst non-partnered fathers was related to whether or not they subsequently moved in with the mother and their child. Here we investigate the importance of this factor on the probability of the continuing non-resident fathers being in involved with their child in later infancy. Again we combined father's presence at birth and being on the birth certificate. Table 6 shows the distribution of this variable for whether the residentially separated fathers were in contact, paid maintenance, saw their child at least weekly, and whether the mother described the father as being very interested in his child and whether they were on friendly terms. Overall, amongst the set of fathers who had not moved in with their child, the two largest groups were those neither at the birth nor on the birth certificate (39 per cent of the fathers) and the set who were on both ( 32 per cent), 24 per cent were only recorded on the birth certificate and only 6 per cent were at the birth but not on the birth certificate. Fathers in these two latter categories may include fathers who were unable to be present due to constraints such as working or living away from the mother's locality.

It is clear from Table 6 that the great majority of fathers who were both present at the birth and included on the child's birth certificate were in contact, and amongst those in contact the great majority saw their child frequently, were very interested in their child, and were on friendly terms with the mother, and 
one in two contributed maintenance to their child. The polar opposite fathers, those who were neither at the birth nor on the birth certificate were much less likely to be in contact but even so almost one three of these fathers were still in contact with their children. Amongst those in contact around one in two saw their children frequently and were on friendly terms with the mother. The two intermediate groups were very similar to each other across most of the domains.

\section{Table 6: Father contact and involvement at 9 months according to involvement at birth}

\begin{tabular}{|c|c|c|c|c|c|}
\hline $\begin{array}{l}\text { Father involvement at } \\
\text { birth }\end{array}$ & $\begin{array}{l}\% \text { in } \\
\text { contact }\end{array}$ & $\begin{array}{c}\text { \% pays } \\
\text { maintenance }\end{array}$ & $\begin{array}{c}\% \text { sees } \\
\text { child at } \\
\text { least } \\
\text { weekly }\end{array}$ & $\begin{array}{c}\% \\
\text { interested } \\
\text { in the } \\
\text { child }\end{array}$ & $\begin{array}{c}\% \\
\text { parents } \\
\text { on } \\
\text { friendly } \\
\text { terms }\end{array}$ \\
\hline $\begin{array}{l}\text { Father neither at the birth } \\
\text { nor on the birth certificate }\end{array}$ & 30 & 12 & 58 & 47 & 61 \\
\hline On birth certificate only & 68 & 30 & 83 & 65 & 75 \\
\hline At the birth only & 72 & 37 & 72 & 61 & 66 \\
\hline $\begin{array}{l}\text { At the birth and on the } \\
\text { birth certificate }\end{array}$ & 88 & 54 & 89 & 77 & 81 \\
\hline Total Percentage & 62 & 35 & 80 & 68 & 73 \\
\hline Numbers in sample & 3044 & 3390 & 2204 & 3515 & 1851 \\
\hline
\end{tabular}

For this set of non-resident fathers, we were also interested in assessing the relative importance of the birth involvement measures with later father contact and involvement after taking into account other attributes of the families, as well as ascertaining what other factors are associated with enhanced father contact and involvement in later infancy. To this end we fitted a series of logistic regression models that included the combined measure of father's involvement at the time of the birth, the demographic profiles of the parents, and additional information on the socio-economic circumstances, well-being and living arrangements of the mother at the time of the interview when their baby was 9 months old.

The socio-economic measures included: whether at the time of the interview the mother was in paid work ( 23 per cent of these mothers were in paid work which is much lower than the figure of 51 per cent for all the mothers in the sample); and whether the family was living in poverty, ( 79 per cent were defined as being below 60 per cent of the median equivalised household income as constructed by Mayhew and Bradshaw, 2005, compared with 28 per cent in the sample as a whole). Information on the mental well-being of the mother was 
included in our analyses as we wanted to investigate whether there was any association between the father's visibility and the mother's well-being. We examined three indicators of well-being: levels of self-esteem, life satisfaction, and whether the mother was depressed. The life satisfaction indicator was the strongest discriminator and is shown in the multi-variate analyses reported here. This indicator was derived from the responses to a question on 'how satisfied or dissatisfied you are about the way your life has turned out so far'. The mothers were asked where on a scale from 1 to 10 they would place themselves with 1 being completely dissatisfied and 10 being completely satisfied. A score of 6 or less was taken to indicate low levels of life satisfaction with 20 per cent of all the MCS mothers falling into this category and 37 per cent of the solo mothers. The living arrangements of the mother was also included in the analysis in terms of whether she was living on her own, with a partner other than the father of her child, or in a household that contained a grandparent of the baby. The majority of these mothers were living on their own ( 75 per cent), but grandparents are also an important feature of the lives of these new parents as one in five ( 22 per cent) were living with their parents at the time of the interview. There is evidence that where a new partner has arrived that the father is more likely to lose contact and less likely to pay maintenance (Maclean and Eekelaar, 1997; Bradshaw et al, 1999); however in this study of new parents, repartnering was rare, only 2 per cent were living with a new partner by the time their child was 9 months old. As time goes by and more of the mothers enter new relationships then it is likely that more of these fathers will lose contact with their children.

\section{Contact and payment of maintenance}

The first two columns in Table 7 shows the odds ratios, derived from multivariate logistic regression analyses, for whether the non-resident fathers were in contact or paid maintenance with respect to the specified factors. ${ }^{9}$ There was a tiny minority of fathers, 5 per cent, who paid maintenance but were not in contact with their children. In this analysis we have reduced the number of categories in some of the variables, as more detailed categories did not contribute any additional insights.

Logistic regression analysis allows us to measure the effect of various factors on for example contact and payment. Logistic regression estimates the effect of a factor or variable after taking into account the effects of the other variables in the analysis. It provides an estimate of the probability of a factor occurring when a parent is in a certain group compared to a reference category. This effect is measured in terms of a relative risk ratio for factors that would impact on whether a father is in contact with his child. Each relative risk ratio predicts the odds of a parent being in a specific group as compared to a baseline group. The baseline groups are those shown first in the set or where it is a dummy variable the converse is the baseline category. 
It is clearly apparent from the multi-variate analyses shown in Table 7 that the extent of the father's involvement at the birth is an important determinant of whether they are in contact or pay maintenance. Being at both the birth of the child and on the child's birth certificate is by far the strongest association seen here. Fathers who were only at the birth or only on the birth certificate exhibit similar but significantly lower odds of being in contact and paying maintenance compared with fathers present on both (tested separately) or not present at either.

There was little suggestion from the multivariate analyses on contact and payment of maintenance that the odds that a father would be in contact or pay maintenance varied much according to the age of the parents, father's ethnic group (with the exception that fathers of mixed race were more likely than white fathers to be in contact and pay maintenance), nor did the odds vary according to the financial and emotional well-being of the mother or with her residential arrangements. However, there is evidence that mothers with more human capital and economic resources (in terms of having qualifications or being in work) were more likely to be in receipt of maintenance than those without qualifications or not in work. It may be that mothers with more education and or with jobs may be better able than other mothers to negotiate with the non-resident fathers, perhaps because they have greater skills and confidence. The fathers of these children may also be more likely to be in work or have higher incomes. These findings with respect to employment and education are in accord with more general studies of families with absent fathers such as those of Bradshaw et al (1999) and Marsh and Perry (2003).

\section{Frequency of involvement}

Turning to whether the father saw the child at least weekly or less frequently, again we see the importance of father involvement at birth, and the pattern is broadly similar to that seen with regard to contact and maintenance. There were also some ethnic differences in the frequency with which the father saw their child; generally speaking all the groups of ethnic minority fathers were less likely than white fathers to see their child on a weekly basis or less, but only for Black fathers, those with origins in the Indian sub continent and those of other races were the odds ratios significantly different from the baseline group of white fathers. None of the other factors clearly distinguished between fathers who saw their children at least weekly versus less frequently. Unfortunately, information on the physical distance between the homes of the two parents was not included in the baseline survey of the MCS, particularly as distance has been shown to be amongst the most important determinants of the frequency with which a father sees his child (Blackwell and Dawe, 2003). 
Table 7: Odds ratios for father's association with child by parental characteristics

\begin{tabular}{|c|c|c|c|c|c|}
\hline & $\begin{array}{c}\text { Father in } \\
\text { contact }\end{array}$ & $\begin{array}{l}\text { Father pays } \\
\text { maintenance }\end{array}$ & $\begin{array}{c}\text { Father } \\
\text { sees child } \\
\text { at least } \\
\text { weekly }\end{array}$ & $\begin{array}{l}\text { Father is } \\
\text { very } \\
\text { interested } \\
\text { in the child }\end{array}$ & $\begin{array}{c}\text { Parents } \\
\text { are on } \\
\text { friendly } \\
\text { terms }\end{array}$ \\
\hline \multicolumn{6}{|l|}{ Characteristic } \\
\hline $\begin{array}{l}\text { Father neither at birth nor on } \\
\text { the birth certificate }\end{array}$ & 1.0 & 1.0 & 1.0 & 1.0 & 1.00 \\
\hline $\begin{array}{l}\text { Father on birth certificate } \\
\text { only }\end{array}$ & $4.8 * * *$ & $4.3 * * *$ & $1.9^{* *}$ & $1.7^{*}$ & 1.2 \\
\hline Father at birth only & $6.7 * * *$ & $3.5^{* * *}$ & $3.3 * * *$ & $1.9^{*}$ & $1.7^{*}$ \\
\hline $\begin{array}{l}\text { Father at birth and on the } \\
\text { birth certificate }\end{array}$ & $15.2 * * *$ & $8.9 * * *$ & $5.1 * * *$ & $3.6 * * *$ & $2.9 * * *$ \\
\hline \multicolumn{6}{|l|}{ Mother's qualifications } \\
\hline Some & 1.24 & $1.46^{* * *}$ & 0.9 & 1.1 & 0.9 \\
\hline \multicolumn{6}{|l|}{ Mother's age at birth } \\
\hline Under age 20 & 1.0 & 1.0 & 1.0 & 1.0 & 1.0 \\
\hline 20-24 years & 0.9 & 1.1 & 0.9 & 1.1 & 1.2 \\
\hline 25and older & 1.0 & 0.9 & 0.8 & 0.8 & 0.6 \\
\hline \multicolumn{6}{|l|}{ Father's age at birth } \\
\hline Under age 24 & 1.0 & 1.0 & 1.0 & 1.0 & 1.0 \\
\hline 25-34 years & 0.9 & 1.1 & 0.9 & 1.1 & 1.1 \\
\hline 35 and older & 1.2 & 1.1 & 0.8 & 1.0 & $1.7^{*}$ \\
\hline \multicolumn{6}{|l|}{ Father's ethnic origin } \\
\hline White & 1.0 & 1.0 & 1.0 & 1.0 & 1.0 \\
\hline Mixed & $2.8^{* * *}$ & $2.1 * *$ & 0.6 & 1.9 & 0.7 \\
\hline Indian & 1.4 & 0.7 & $0.2 * *$ & 2.2 & $4.6^{*}$ \\
\hline Pakistani/Bangladeshi & 0.9 & 0.9 & 0.7 & 0.8 & $0.5^{*}$ \\
\hline Black & 0.9 & 0.9 & $0.6^{*}$ & 1.1 & 1.1 \\
\hline Other & 0.8 & 0.8 & $0.3^{* *}$ & 3.0 & 2.0 \\
\hline Mother in work & $1.4+$ & $2.0 * * *$ & 0.9 & 0.9 & 1.0 \\
\hline Low income & 0.9 & 0.8 & $1.5+$ & 1.2 & 1.3 \\
\hline $\begin{array}{l}\text { Mother has a low level of } \\
\text { life satisfaction }\end{array}$ & 1.1 & 0.8 & 0.9 & $0.6 * * *$ & $0.5^{* * *}$ \\
\hline \multicolumn{6}{|l|}{ Living arrangements } \\
\hline On own & 1.0 & 1.0 & 1.0 & 1.0 & 1.0 \\
\hline Partner in household & 1.3 & 0.9 & 0.6 & 1.1 & 1.8 \\
\hline Grandparent in household & 0.8 & 1.3 & 0.7 & 1.1 & 0.9 \\
\hline
\end{tabular}




\section{Interest in the child and parental relations}

A different set of insights emerged with respect to the more emotional aspects of involvement as assessed by whether the mother viewed the father as being very interested in their child, or whether she reported that they were on very friendly terms or not. For these dimensions we see that where fathers are categorised as being very interested in their child, and where the parents are on very friendly terms the mother is much less likely to express a low level of life satisfaction, which suggests that father contact may influence the well-being of mothers as well as their children. With regard to ethnicity the only statistically strong associations were that fathers classified as being of Indian origin were much more likely than white fathers to be on very friendly terms with the mother and that the opposite was the case for the group of Pakistani and Bangladeshi fathers. Where fathers are older (over age 35) the mother is also more likely to report that they are on friendly terms. We also note that parental relations in terms of degree of friendliness amongst those where a father was only on the birth certificate were not significantly different from the baseline group of fathers who were neither at the birth or on the birth certificate, suggesting that for some parents the presence of the father's name on the birth certificate may represent a more formal recognition than necessarily a personal attachment to the mother and child.

This resonates with findings from US studies. For example, Coley and ChaseLansdale (1999) found that a closer mother-father relationship encouraged involvement of unmarried fathers with their young children. An analysis of the US Fragile Families Study by Carlson and McLanahan (2005) which looked directly at relationship quality amongst unmarried parents found that relationship quality influenced the quality of parenting of both unmarried mothers and fathers.

\section{Overview and conclusions}

Judged by these data from the Millennium Cohort Study, 15 per cent of children are born to parents who are not in a union and probably not co-residing. This is a new and quite striking development in family life considering that as recently as the early 1980s the totality of births outside of marriage was around 13 per cent. This analysis has provided insights into the extent to which the fathers in these families are engaged with their off-spring at the time they are born and in later infancy. The great majority of the babies born outside of marital and cohabiting unions were unplanned, but one in two of the fathers of these babies acknowledged their fatherhood by being present at the birth and two out of three did so more formally by being included on the child's birth certificate. Presence at the birth and being the formally recorded father were important independent 
predictors of whether the father subsequently moved in with the mother, and for those fathers who continued to live apart the extent to which they were in contact and involved in their child's life.

By the time the child was 9 months old, 24 per cent of the fathers were living with their child either full-time (14 per cent) or part-time (10 per cent), 45 per cent were non-resident but in contact with their child, and 31 per cent had no contact. This latter figure constitutes about 5 per cent of all the babies in the MCS, and the fathers of these children may be permanently lost from their children's lives. At the other end of the spectrum, the fathers who were now living with the mother full-time were as actively engaged in caring for their babies as the fathers who were married or cohabiting from the outset, suggesting that in this domain there is little negative legacy of precipitated fatherhood.

The over-sampling of ethnic minorities in the MCS allowed the examination of variation in behaviour across ethnic groups, but even so some of the analyses are based on a small numbers of cases, so we should be cautious about generalising the findings. There was evidence that relative to white parents, that solo mothers of Indian extraction were more likely to have the father of the baby move in, and all these fathers moved in on a full-time basis. In contrast, amongst Black families of Caribbean origin, relative to white families, the father was less likely to move in with the mother and child, but where they did so this was relatively more likely to be on a part-time basis. Part time living may be related to the notion of visiting unions, which is a significant component of partnership behaviour amongst Black families in the Caribbean (Lightbourne and Singh, 1982). Amongst the non-resident fathers, there was little variation across the main ethnic groups in the extent to which they were in contact or paid maintenance, but amongst those in contact the ethnic minority sets of fathers were less likely to see their children on a weekly basis compared with white fathers.

The MCS collected very limited information on non-resident fathers and we have no information on their socio-economic circumstances. However, there is indirect information from this study (and more direct information from others) that such fathers may be more likely to be economically disadvantaged than other fathers. We saw earlier that one in two of the children in the MCS who were born to parents who were neither married nor cohabiting were living in disadvantaged wards. There is also evidence from analyses of the NCDS and BCS 70 cohort data that non-partnered fathers are more likely to have had disadvantaged backgrounds (Kiernan, 1997 and 2003) and there is ample evidence from the US literature that the partnership and reproductive behaviour of men and their responses to fatherhood are shaped by economic resources 
(Forste, 2002, FFS). Speak et al (1997) in their in-depth study of young single fathers in Newcastle highlighted the interconnections between work and family life, and how economic marginalisation can affect family obligations. Thus, socioeconomic disadvantage may well be an important factor in preventing these fathers from assuming their parental role and continuing to be involved in their children's lives. Elder (1985) has suggested that men who become fathers but lack the financial resources to provide for a family experience role strain or conflict, with disparities between expectations and resources possibly resulting in a loss of control over one's life, which requires adaptation to restore control. If access to resources is limited then control may be more readily regained by avoiding family obligations. Mothers may also prefer lone motherhood to living with a man who they were uncertain they could rely on for financial support (Smart and Stevens, 2000). Poorly endowed parents may prefer or may be constrained to live apart, which limits a father's parenting opportunities.

This study has provided some statistical visibility but limited descriptive information on non-partnered and non-residential fatherhood. Why some of these 'separate' fathers choose to be involved parents whereas other men who are aware of their paternity avoid parental obligations from the outset cannot be answered from this particular study, nor can we provide insights into the extent to which either lack of co-residence or lack of involvement arises from choice, constraints or contingencies. The MCS has highlighted the diversity and volatility in family situations that prevail at the time a child is born and in later infancy and provided new information on solo parenthood. If solo mothers and their children are to be supported we need a clearer understanding of the role that these new fathers play, which includes their reactions to fatherhood and what might help or prevent their positive involvement in their child's upbringing. The other intriguing question that also remains unanswered is why this form of fatherhood is much more prevalent in Britain than in other European countries? 


\section{References}

Andersson, G (2002) 'Children's experience of family disruption and family formation: evidence from 16 FFS countries', Demographic Research [Online] 7: 343-364 at http://www.demographic-research.org.

Barlow, A. (2004) 'Regulation of Cohabitation, Changing Family Policies and Social Attitudes', Journal of Law and Policy, 26(1): 57-86.

Bianchi, S. (1998) 'Introduction to the Special Issue: Men in Families', Demography, 35(2): 133.

Blackwell, A and Dawe, F (2003) Non-Residential Parental Contact Final Report, Social and Vital Statistics Division. London: ONS.

Bradshaw, J., Stimson, C., Skinner, C., and Williams, J. (1999) Absent Fathers? London: Routledge.

Carlson, M., and McLanahan, S. (2005) Do partners make good parents: Relationship quality and parenting in married and unmarried families, Center for Research on Child Wellbeing, www.crcw@princeton.edu/workingpapers.

Coley, R., and Chase-Lansdale, L. (1999) 'Stability and change in paternal involvement among urban African American fathers', Journal of Family Psychology, 13,416-435.

Elder, G (1985) Life Course Dynamics: Trajectories and transitions. New York: Cornell University Press.

Families Need Fathers website www.fnf.org.uk

Ford, R., Marsh, A., and McKay, S. (1995) Changes in Lone Parenthood, Department of Social Security Research Report, 40. HMSO: London.

Forste, R (2002) 'Where are all the men? A conceptual analysis of the role of men in family formation', Journal of Family Issues, 23(5): 579-600.

Furstenberg, F.F. (1988) 'Good dads-bad dads: two faces of fatherhood', in J.L. Palmer and I.V. Sawhill (eds) The changing American family and public policy. Washington DC: Urban Institute Press.

Home Office (1998) Supporting Families: A Consultation Document. London: HMSO.

Kiernan, K. (1997) 'Becoming a Young Parent: A longitudinal study of associated factors', British Journal of Sociology, 48(3): 406-428.

Kiernan, K. (2003) 'Legacies of unmarried parenthood: evidence from a longitudinal study'. Paper presented at the Population Association of America Meeting, Minneapolis, April 
Kiernan, K (2004) 'Unmarried Cohabitation and Parenthood in Britain and Europe', Journal of Law and Policy, 26(1): 33-55.

Kiernan, K. and Smith, K. (2003) 'Unmarried Parenthood: New Insights from the Millennium Cohort Study', Population Trends, 114, 23-33.

Lewis, C (2000) A man's place is in the home: Fathers and families in the UK. York: Joseph Rowntree Foundation.

Lewis, J (2001) The End of Marriage? Cheltenham: Edward Elgar.

Lightbourne, R and Singh, S. (1982) 'Fertility, Union Status and Partners in the WFS Guyana and Jamaica Surveys', Population Studies, 36(2): 201-225.

Maclean, M and Eekelaar, J. (1997) The Parental Obligation. Oxford: Hart Publishing.

Marsh, A and Perry, J (2003) Family Change 1999 to 2001, Research Report No.180, Department of Work and Pensions, HM Stationery Office. Leeds: Corporate Document Services.

Mayhew, E. and Bradshaw, J. (2005) 'Poverty and Childbirth', in S. Dex and H. Joshi (eds) Babies of the New Millennium. London: Centre for Longitudinal Studies.

ONS, (1996) Social Focus on Ethnic Minorities. London: Government Statistical Service.

ONS, (2004) Birth Statistics 2003, Series FM1, No.32, London: Government Statistical Service.

Scott, A., Pearce, D. and Goldblatt, P. (2001) 'The sizes and characteristics of the minority ethnic populations of Great Britain - latest estimates', Population Trends, 105: 6-15.

Shepherd, P., Smith, K., Joshi, H. and Dex, S. (2004) Millennium Cohort Study First Survey: A guide to the SPSS dataset (3rd Edition), http://www.cls.ioe.ac.uk/Cohort/MCS/mcsmain.htm.

Smith K and Joshi H (2002) 'The Millennium Cohort Study', Population Trends, 107: 30-34.

Smart, C. and Stevens, P. (2000), Cohabitation Breakdown. London: Family Policy Studies Centre.

Speak, S., Cameron, S and Gilroy, R (1997) Young single fathers: participation in fatherhood -bridges and barriers. London: Family Policy Studies Centre. 